

\section{EXCHANGE}

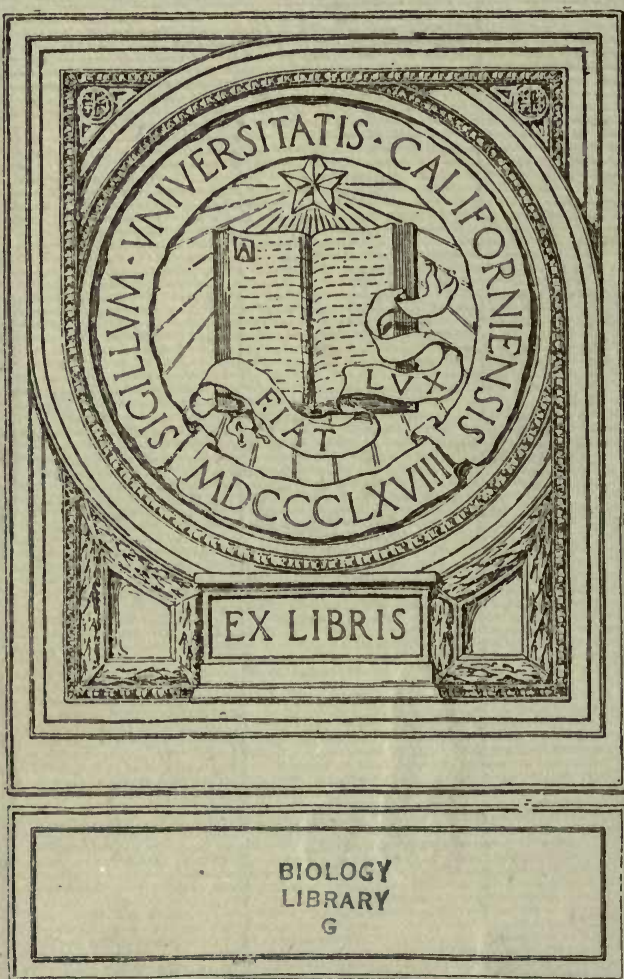




\title{
A CONTRIBUTION TO THE KNOWLEDGE OF THE INTERNAL ANATOMY OF TRICHOPTERA
}

\author{
A Thesis \\ Presented to the Faculty of the Graduate School of \\ Cornell University for the degree of \\ Doctor of Philosophy
}

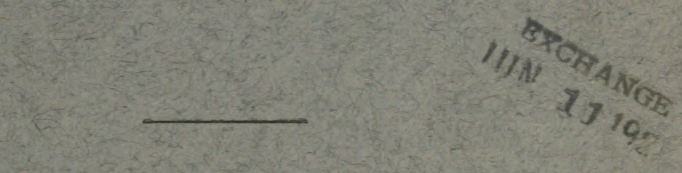

I

By nit

HAZEL ELISABETH BRANCH

Reprinted from the Annals of the Entomological Society of America Vol. XV, pp. $256-280$

Columbus, Ohio: September, 1922 



\title{
A CONTRIBUTION TO THE KNOWLEDGE OF THE INTERNAL ANATOMY OF TRICHOPTERA
}

\author{
A Thesis \\ Presented to the Faculty of the Graduate School of \\ Cornell University for the degree of \\ Doctor of Philosophy
}

By

HAZEL ELISABETH BRANCH

Reprinted from the Annals of the Entomological Society of America Vol. XV, pp. $256-280$

Columbus, Ohio: September, 1922 


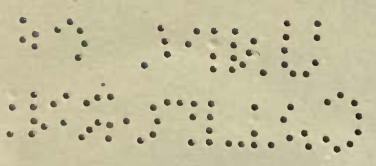

\title{
A CONTRIBUTION TO THE KNOWLEDGE OF THE INTERNAL ANATOMY OF TRICHOPTERA.*
}

\author{
By Hazel Elisabeth Branch, \\ Wichita, Kansas.
}

\section{NERVOUS SYSTEM. $\dagger$}

The nervous system of the trichopterous larvæ is comparatively primitive and agrees with that of the lepidopterous larvæ in the number of pairs of ganglia and also resembles, in some respects, the arrangement in relation to the body segments. Exclusive of the ganglia in the head, which are normal in number and position, there are three pairs for the thorax and eight pairs for the nine abdominal segments, the seventh abdominal segment being the most posterior in which ganglia are found.

In the head of Limnophilus indivisus the supra-œsophageal ganglia are situated with their anterior margin on a line immediately posterior to the eyes. The combined width of the ganglia is about one-half that of the head. Each ganglion gives off laterally and in a forward direction, an optic nerve which branches to supply each of the simple eyes of the visual area. In front of the junction of the two ganglia is the frontal ganglion, small and shield shaped, connected to the supraœesophageal ganglia by a pair of arms. Proceeding from each arm of the frontal ganglion, close to its attachment with the supra-œesophageal ganglion, is a nerve which extends forward and sends an outer branch to the labrum, and an inner branch to the dorsal region of the buccal cavity, see Plate XIV, Figs. 4 and 5 , at $1 \mathrm{~b}_{1}$ and $\mathrm{b}$. Between the point of attachment of the arm of the frontal ganglion with the supra-œsophageal ganglion, and the optic lobe, (opt), is the slender antennal nerve rising from the anterior margin of the ganglion and possessing a fellow in like position upon the other ganglion, see Plate XIV, Figs. 4 and 5 at ant. Upon its posterior face, each ganglion gives rise to a protuberance from which issues a nerve that converges toward its fellow and meets it upon a median line. At this union a small ganglion is formed and to this are also joined, the nerves coming from the sympathetic ganglia. These sympathetic ganglia are single, one upon each side of the œsophagus and possessing a nerve connection with the posterior protuberance of the supra-œsophageal ganglion of its respective side, See Plate XIV, Figs. 4 and 5.

The recurrent nerve of the frontal ganglion extends in a posterior direction between the supra-œsophageal ganglia and the œsophagus

* A contribution from the Department of Entomology, Cornell University, prepared under the supervision of Dr. O. A. Johannsen, to whom and also to Dr. J. G. Needham and Dr. J. T. Lloyd, I wish to express my gratitude for the valuable assistance rendered.

† In gross dissection, hot water killing and Gilson's fixing solution were found to be most advantageous.

EXCHANGE 
and fuses with the nerve which extends posteriorly from the ganglion situated at union of the nerves from the posterior protuberances of the supra-œesophageal ganglia and the sympathetic ganglia of each side.

From the ventral face of the supra-osophageal ganglia, arises a pair of connectives, the crura cerebri, which connect the supra-œsophageal ganglia with the sub-œsophageal ganglion.

Immediately in front of the union of the crura cerebri with the supra-œsophageal ganglia, the œsophageal ring of the tritocerebrum arises. This is a loop which encircles the osophagus and has its ends connected with the supra-œsophageal ganglia, see Plate XIV, Fig. 5 at or. The supra-œsophageal ganglia does not fit closely upon the œsophagus normally, but leaves some space laterally and ventrally for the expansion of the tube in feeding. Faivre 1857, states that the supra-œsophageal ganglia possess the seat of motive power and will power and Binet, 1894 , strengthens this statement by the results of his own experiments which show that an insect will live for months with the supraœsophageal ganglia removed but will not eat unless the food is placed in its mouth as it has no power to move toward the food.

The sub-œsophageal ganglion is situated slightly back of the posterior margin of the supra-œsophageal and below the œsophagus but well within the limits of the head cavity. This ganglion gives off three pairs of nerves, the most ectal and dorsal of which extends in a forward and upward direction and, upon a level with and in front of the frontal ganglion, branches. One branch extends to the base of the labrum, see Plate XIV, Figs. 5 and 6 at 1b2, while a second branch extends to the dorsal side of the mandible, see Plate XIV, Figs. 5 and 6 at md2. The second pair of nerves from the sub-œesophageal ganglion arises ventrad of the first pair and extends forward also branching. The ectal branch of each nerve reaches the musculature of the maxilla, $\mathrm{mx} 1$; and an ental branch divides and one part goes to the maxillary sclerite and the other to the labium, see Plate XIV, Figs. 5 and 6 , at mx2 and li2. This pair is connected by a nerve just below the frontal ganglion, and the cross nerve bears a small median ganglion. The third pair of nerves is ventrad of the second pair and extends forward directly to the labium, which it innervates, li1.

The above description is made from several dozen specimens of the species Limnophilus indivisus Walker. The head ganglia of the other species studied do not vary materially.

Posteriorly the sub-œesophageal ganglion gives off a pair of commissures which connect to the first thoracic* ganglion lying in the prothorax. In the thorax and abdomen there is much variation among the species as to the relation of the ganglia to their respective segments. Upon observation of these three species (Limnophilus indivisus Walker, Hydropsychodes analis Banks and Phryganea interrupta Say,) two centers of fusion will be found, one in the thorax and one in the abdomen at the posterior end of the chain. As above stated, there are three thoracic and eight abdominal ganglia. The prothoracic and

\footnotetext{
* Each ganglion of the thorax and abdomen is a pair of fused ganglia.
} 


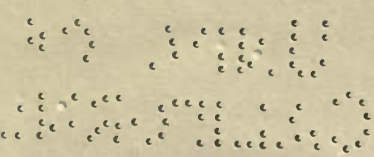

mesothoracic ganglia are about the same size as the sub-œsophageal ganglion and are each situated equidistantly from the anterior and posterior margins of the segments and this condition prevails for the three species. The metathoracic ganglion is larger than those of the preceding segments and its position is not the same in the different species for it is here that the thoracic fusion point occurs. In Phryganea interrupta the ganglion is centrally located with the ganglion of the first abdominal segment just within the posterior border of the metathorax. In Limnophilus indivisus, the metathoracic ganglion has migrated forward and the first abdominal ganglion has followed until the latter occupies the central position with the metathoracic ganglion well in the front half of the segment. In Hydropsychodes analis, the condition is the same as in L. indivisus.

In the abdomen of the three species the positions of the ganglia are more noticeably variable. In $P$. interrupta the first abdominal segment bears at its posterior margin, the ganglion of segment two and segment two is void of any ganglion, but receiving its innervation from its respective ganglion located in segment one. The ganglia of segments three, four, five and six occur in their respective segments near the front margins. Segment seven bears in its front half, two ganglia; these are the ganglia for segments seven and eight and they are very closely united, but not fused at all, Plate XIV, Fig. 2. In $L$. indivisus, the ganglion of segment two occupies a central position in segment one, indicating a forward migration. Segments three, four and five have their ganglia in the front half of the segment as in $P$. interrupta. In segment six all the ganglia of the three segments, six, seven and eight, are placed; those relating to segments seven and eight are closely united, practically fused, and take a position in the posterior half of the segment. The ganglion for segment six is in the anterior half of the segment, Plate XIV, Fig. 1 . In H. analis we find an arrangement in the abdomen which varies from that which Pictet, 1834, observed in Hydropsyche, for he saw all the ganglia here upon the divisions between the segments. In this particular species, the ganglion for segment two is in segment one as usual, and the ganglion for segment three is on the margin between segments two and three which is a forward migration. The ganglion for segment four is in front of the center of the segment and the ganglion for segment five is back of the center of its respective segment. In the sixth abdominal segment are three ganglia, for segments six, seven and eight respectively and all are in a line and practically fused, Plate XIV, Fig. 3.

The thoracic ganglia and the abdominal from one to six innervate their respective segments and appendages, the seventh abdominal appears to have only one pair of nerves which extend backward into segment seven, the eighth abdominal ganglion innervates segment eight and nine, as well as the swimmerets, which extend out from segment nine. There are various ways for the eighth abdominal segment to innervate segment nine. In $P$. interrupta and $H$. analis it sends a nerve directly to the segment, but in L. indivisus the nerve which extends to segment eight branches and sends a branch to segment 
nine, this arrangement leaves one less pair of nerves arising from ganglion eight in $L$. indivisus than in P. interrupta or $H$. analis.

Upon a comparison of the three Figures, Nos. 1, 2 and 3, Plate XIV, a sequence of fusion is evident. This sequence places $P$. interrupta as the most generalized and $H$. analis as the most specialized and $L$. indivisus as intermediate. Vorhies, 1905, has described the nervous system of Platyphylax designatus Walker and it falls between $P$. interrupta and $L$. indivisus for the ganglia of the seventh and eighth segments have migrated so that the ganglion for segment seven is just inside the posterior margin of segment six and the ganglion for segment eight remains in segment seven, but very close to its anterior margin. Betten, 1901, in his description of Molanna cinerea does not show it to vary from $P$. designatus. Pictet, 1834, figures Phryganea striata Fab. to fall between $P$. designatus and $L$. indivisus with the ganglia for segments six, seven and eight in segment six, but ganglia seven and eight not fused. Klapalek, 1888, does not note any variation of position, but merely gives the number of ganglia and their general distribution.

From the above it seems reasonable to think that the nervous system of the order will reveal grades of consolidation of the ganglia which may have a decided bearing upon classification.

\section{REPRODUCTIVE SYSTEM.}

The writer has done very little in this system beyond the mere location of the organs, for the matter seems to have been given adequate attention by Zander, 1901, Lubben, 1907, and Marshall, 1907. As to the period of the appearance of the organs there is a difference of opinion. Pictet, 1834, Klapalek, 1888, and Vorhies, 1905, make the statement that the organs do not appear until near the period of pupation or at least in a very old larva; Lubben, 1907, discusses conditions in a transforming larva, while Marshall, 1907, speaks of the condition of the organs in the youngest larva he had, but does not give the stage. In all the specimens observed by the writer, the gonads appear in the early forms, showing clearly both in gross dissection and sections. In $P$. interrupta taken in October and $H$. analis taken in late December from under the ice in streams, the gonads are distinct and developed far enough so that tubules may be seen, Plate XIV, Fig. 7. This period is long before there are any signs of pupation either in case or larva.

Within the species two shapes of gonads appear. In $P$. interrupta some are elongate and flat, while others are spherical. This seems to point to a sex differentiation, the elongate one probably destined to become female organs and the spherical ones male organs, Plate XIV, Fig. 2. In gross dissection in L. indivisus only one kind of a gonad was observed, this circular and plate-like of five pairs of tubules. Plate XIV, Fig. 1, at gd. In each gonad there are two outgrowths or attachments; one from the outer side and extending to the ventral body wall of the second abdominal segment and resembling a supporting thread or tissue, the inner side outgrowth appears as a duct and the tubules of the gonad may be seen converging toward the head of this duct. 
The duct extends in a posterior direction and extends to the ventral side of the eighth segment, where it is lost. Lubben, 1907, shows that these ducts pass into external, sculptured plates in the eighth segment but I have been unable to find any such structure or any opening whatever at this point on any of the specimens. In $H$. analis the gonad is oval, but appears spherical in frontal section as the long axis of the gonad is at right angles to that of the body of the larva. The gonads of the above three species are in pairs and lie in the fifth segment of the abdomen Betten, 1901 finds the gonads for $M$. cinerea in segment four; Lubben, 1907, records Anabolia nervosa and Limnophilus stigma as having the organs in segment five, Rhyacophila septentrionis and Brachycentrus montanus in segment four. Klapalek, 1888, gives the gonads a general location of segment three, but neither literature nor my own observations uphold this statement. From a compilation of records the position appears to be in either the fourth or fifth segment.

\section{ALIMENTARY CANAL.}

General description: The alimentary canal, in the order Trichoptera, passes as almost a straight tube from buccal cavity to anus. Pictet, 1834, figures the tube as practically undifferentiated in its shape and only varying slightly in size at the extreme ends. Klapalek, 1888, states that the regions merge imperceptibly into each other: Although this concition may be true in a specimen gorged with food, the writer has never seen a specimen where the three main divisions of stomodeum, mesenteron and proctodeum were not distinctly marked one from the other. The lack of convolutions as are normal in the alimentary canals of insects which are herbivorous, is unusual, as Siltala, 1907, shows that the order is in the main herbivorous and yet this general type of a straight tube prevails. There are a few semi-carnivorous species, but even here there is no variation from the above condition. The assimilative area is increased by an unusual width in proportion to that of the body, for in many places and especially the mesenteron, the width is equal to one-third and frequently more than one-third the width of the abdomen. Another device adds to this area or surface for the wall of the mesenteron is folded into transverse ridges which increase the surface by three times that actually occupied by the wall, Plate XV, Fig. 10. These folds are deeper in the strictly herbivorous types, such as $L$. indivisus, than in those which are more or less carnivorous, as $H$. analis. We will pass now to a discussion of the alimentary canal in the three species. Hydropsychodes analis Banks, Plate XV, Figs. 7,8 and 9 . The surface of the stomodeum of the alimentary canal presents a silvery appearance, due to the peritoneal covering of the muscles which surround and control the activities of this portion of the canal. This portion is much darker than the remainder of the canal, due to the food within. If this be cleaned, the wall appears transparent. Beneath the peritoneal membrane can be seen the longitudinal muscles arranged in pairs in six equi-distant places around the canal. Underneath these longitudinal muscles lie the circular muscles, which are so 
heavy and thick that they give the canal the appearance of having great rings around it. The stomodeum is composed of four parts, namely: buccal cavity, œesophagus, crop and proventriculus. The buccal cavity is large, including half the depth of the head capsule, it narrows rapidly and passes over into a slender tube which passes beneath the supra-œesophageal ganglia as the œsophagus. The osophagus extends backward through the head and prothorax with only slight expansion. At the posterior margin of the prothorax it begins to enlarge and extends through the length of the mesothorax with a diameter one-third that of the thorax and four times the diameter of the œesophagus in the prothorax. This is the crop. At the posterior margin of the mesothorax the stomodeum is suddenly constricted to about half its width and within a longitudinal distance of $.5 \mathrm{~mm}$. suddenly enlarges to form a cylindrical structure, the wall of which becomes resistant to dissecting instruments and is very hard. The circular muscles are larger and heavier in this region and inside the tube are chitinized teeth. This portion is the proventriculus, which functions as a grinding organ and possibly as a straining device.

The cylindrical shape ends suddenly at the posterior margin of the metathorax and the transition into the mesenteron is well indicated by change in color, texture and structure of the wall and by a deep fold. The proventriculus pushes into the forward end of the mesenteron and forms there an œsophageal valve. The mesenteron folds up over the proventriculus and causes a distinct line to appear between the two portions. The silvery tone of the wall is lost at this juncture; the longitudinal muscles break up to form a layer of muscles around the mesenteron and this layer extends the full length of the mesenteron. Beneath these muscles can be seen the very thin layer of circular muscles. The mesenteron enlarges at its beginning to at least a third the diameter of the abdomen of the larva and increases slightly toward the fourth segment and then returns to its width at the beginning before it reaches its length. This division arises at the posterior end of the metathorax and extends through the length of the abdomen as an almost straight tube, varying only as above in diameter, circular in cross section, and possessed of an extremely thick wall, but one that is easily torn apart. In the sixth segment the mesenteron becomes about two-thirds the diameter at its beginning and passes over into the proctodeum. The proctodeum is composed of intestine, both large and small, and the rectum. The mesenteron pushes into the intestine in much the same manner that the proventriculus pushes into the mesenteron, but the distance is not as great and the valve formed is not a distinct one in this species, although the division between the two main divisions of the canal is clearly marked. At the point where these two portions meet, the Malpighian tubules, of which there are six, make their appearance upon the surface. These tubules are situated upon the lateral and ventral faces of the alimentary canal and the dorsal face is void of them; however, the first pair may be easily seen from a dorsal view, each member of this pair lies upon the upper portion of the lateral face and extends forward through the abdomen and into the metathorax. Slightly 
below the first pair, the second pair arises and extends, each member of the pair upon its respective side of the alimentary canal, forward for the remaining distance of the sixth segment where it turns backward and taking an upward and lateral direction, with regard to the intestine, curves and coils about in the lower part of the abdomen back of the sixth segment. The third pair of tubules is situated upon the venter about equidistant from each other and from the corresponding members of the second pair. This third pair extends backward immediately and each member comes to lie beneath and to the side of. the intestine, intertwining with the corresponding member of the second pair. The tubules are irregular in outline, appearing like small oval beads strung upon a thread. In general color they are a pale, clear yellow, but blotched at irregular intervals with a kidney-brown pigment. They weave in and out among the fat bodies and tracehæ, and into blood sinuses to perform their function of the removal of nitrogenous waste.

The front end of the intestine is cup-shaped with the larger end forward. This portion represents the small intestine. The tube grows smaller as it proceeds toward the caudal end, but in the seventh segment is greatly constricted; it enlarges immediately and passes through segment eight with a diameter of about a fourth that of the segment and two-fifths of the diameter of the mesenteron in the first segment. This portion represents the large intestine.

At the posterior margin of segment eight, the intestine is again constricted and passes over into the rectum. At this juncture there is a semi-valve formed by the invaginated walls of the intestine. These folds become longer and fewer in number and form the blood gills which lie in the rectum. The rectum extends through the ninth segment. In some forms examined, the small diameter of the constricted region at the posterior end of segment seven prevails through the eighth, widening suddenly at the beginning of the ninth to accommodate the invaginations forming the blood gills; in other forms the widening is gradual through the eighth and passes over gradually into the rectum without any noticeable constriction. The wall of the small intestine is heavy and surrounded with circular muscles. It becomes thinner as it extends toward the large intestine. When the rectum is reached the wall is exceedingly thin and almost transparent. Through the wall can be seen the four pockets or invaginations which form the blood gills, and into these muscles extend from the lateral and ventral walls at the conjunctiva between segments eight and nine. The rectum now serves a double function, that of elimination of fecal matter and secondarily that of respiration, when oxygen cannot be obtained by means of the tracheal gills. These blood gills have no tracheæ running into them as a glycerine mount of the caudal portion of a fresh specimen clearly demonstrates. They function, when the larva is out of the water, by protruding themselves through the T-shaped anus, in which state they are filled with blood. A detailed account of their structure will be found elsewhere in this paper. 
Limnophilus indivisus Walker, ${ }^{*}$ Plate XV, Figs. 1, 2, 3 and 5. In this form the osophagus passes from the buccal cavity into the head region where it is a small tube and continues through the prothorax. The crop is absent in this form and the oesophagus passes immediately into the proventriculus. Here the chitinized "teeth" upon the lining such as we find in $H$. analis are lacking. They are not needed, as the form is strictly herbivorous and $H$. analis is semi-carnivorous. The œsophagus begins to enlarge at the posterior edge of the prothorax to form the proventriculus, which lies in the mesothorax. It is silvery in appearance and dark colored, but not resistant to the needle owing to the lack of chitinized teeth within. The proventriculus possesses the six pairs of longitudinal muscles and the circular layer, but these are not as heavy as in $H$. analis. At the posterior margin of the mesothorax the proventriculus constricts slightly and passes over into the mesenteron. This position is contrary to the usual division level for these two portions of the alimentary canal, but the œesophageal valve occurs here and the character of the wall changes to a light pale color, is thicker in cell depth and the six pairs of muscles from the proventriculus form the characteristic layer around the new division. From these characteristic markings there can be no doubt as to this transition. The œsophageal valve is normal, Plate XV, Figs. 2 and 3 show it as a complete invagination of the wall, in a fold of eight projections

The mesenteron takes its beginning in the mesothorax and increases in diameter as it passes through the metathorax. It may be slightly constricted in the first abdominal segment although it frequently passes without any change of contour. It passes through the abdomen at its diameter of one-third that of the abdomen and extends to the sixth segment. Here the transition into the intestine occurs and the juncture is marked by the presence of the six Malpighian tubules, in the same arrangement as in $H$. analis. The tubes are longer, however, and the first pair does not extend into the thorax, but turns backward in the first abdominal segment and returns to the seventh. The second pair frequently extends as far as segment three and then returns to segment eight. The third pair may continue forward through segment six before turning backward. The junction between mesenteron and intestine is marked by a decided valve not found in $H$. analis and similar to the osophageal valve. A section showing this structure is on Plate XV, Fig. 10. The intestine at its forward end is also cupshaped and, at the constriction between small and large intestine, possesses a valve formed by the invagination of the intestinal wall. (Plate XV, Fig. 5). Along the intestine are six muscle bundles which seem to control the initial position of the Malpighian tubules. Marchal, 1892, considers the tubules as being capable of motion and perhaps these muscles have some part in that action. These muscles likewise support the front edge of the rectum into which the large intestine telescopes.

* This species is selected for a comparison with $H$. analis, as the two represent widely divergent forms. 


\section{Phryganea interrupta Say* Plate XV, Fig. 11.}

In $P$. interrupta, the œsophagus passes through the head as a narrow tube and enlarges toward the posterior margin of the prothorax to form a crop of small dimension which is marked from the proventriculus by a slight constriction. The proventriculus occupies the meso and metathorax in length and practically fills the whole of the body cavity in this region, it presents the silvery surface as in the other forms and the longitudinal and circular muscles are evident. The posterior end of the proventriculus extends over into the first abdominal segment and here is constricted suddenly and passes through this segment as a small tube about one-fourth the diameter of the proventriculus in the mesothorax. This constriction is so long that the longitudinal muscles of the proventriculus do not follow the tube but span the distance from the beginning of the constriction to the surface of the mesenteron and can be seen as threads across the open space. $\dagger$

The mesenteron is the same as in the other forms and passes over into the intestine of the proctodeum in the sixth segment where the Malpighian tubules arise. These do not always assume the same positions, which is further evidence of Marchal's theory on their mobility. Marchal, 1892. The intestine extends through segments six and seven and at the anterior margin of the eighth there is a constriction as the intestine passes over into the rectum. The rectum gradually grows smaller as it nears the anus. The anterior portion of the intestine has a heavy musculature and the lower part is ridged longitudinally and these ridges become more prominent in the rectum and form four longitudinal columns which continue to the anus.

\section{HISTOLOGY OF THE ALIMENTARY CANAL. $\ddagger$}

In this work the writer has divided the material into two parts: that dealing with cellular structure and that relating to the musculature of the canal. The condition in $H$. analis is taken as a basis of comparison and where $L$. indivisus differs from the above the condition is noted and illustrated in the figures.

Buccal cavity: The cells are flat and small with small nuclei The cavity is heavily lined with chitin.

* This third species is selected on account of its larger size.

$\dagger$ A normal œsophageal valve occurs at the division between proventriculus and mesenteron.

$\ddagger$ In the histological work, both hot Gilson's and hot Bouin's were used with equal advantage if the material was to be used at once. If more than a month were to elapse before the material would be used, Bouin's was by far the better fixative, as those in Gilson's softened rapidly.

Much better results were attained by clearing in xylol than in cedar oil. An infiltration of not longer than nine hours, including the time in xylol and paraffin, equal parts, at 52 degrees F., produced the material most easily cut.

Staining in Delafield's haemotoxylin and counterstaining in aqueous $1 / 2 \%$ eosin produced excellent results as a general stain. For muscles and epithelial cells, iron haemotoxylin made clearer slides than the above. Paracarmine with a counter stain of orange $\mathrm{G}$. was especially adapted to digestive epithelial tissue in L. indivisus. 
Oesophagus: The cells of the epithelium are cubical and the whole epithelium is lined with a chitinous intima. The basement membrane is distinct between the epithelium and the muscles surrounding the œesophagus.

Crop: Conditions the same as in the œsophagus.

Proventriculus: The cells of the epithelium do not vary from those of the œsophagus but the wall itself is thrown into folds and the intima becomes thick and dense and forms the stomachic teeth, the number of which is about thirty-six. A cross section of this region shows them surrounding the cavity At the posterior margin of the proventriculus is the osophageal valve which in this form is of peculiar plan. It is practically double with a strongly chitinized invagination into the proventriculus and an extremely deep but narrow invagination into the mesenteron. This valve does not completely surround the constriction between the two divisions. For further details see Noyes 1915. This valve in $L$. indivisus is normal and complete. It extends into the mesenteron in a fold, the upper part of which is composed of cubical cells with an extremely heavy intima, while the under portion of the fold although the cells are cubical become somewhat flattened and the intima reduced to a thin membrane. The wall changes suddenly into the columnar structure of the mesenteron with its striated border. At the point where the intima ceases the peritrophic membrane arises. This is separated from the epithelial wall of the mesenteron and surrounds the food in the canal, Plate XV, Fig. 6.

Mesenteron: The epithelium here is similar to that at the posterior end of the œsophageal valve except that the cells become more columnar. The conditions in function accord with those described in the dragonfly nymph, Needham, 1907, and need no further discussion here The wall of the mesenteron is folded as mentioned in the discussion of the gross anatomy of the canal to produce more assimilative surface and this condition prevails the entire length of the mesenteron to the sixth segment. In this same segment the Malpighian tubules show upon the surface and the mesenteron passes over into the intestine, Plate XV, Fig. 10 at dep.

Malpighian tubules: At the posterior end of the mesenteron where the cells are still columnar, the ventral pair of Malpighian tubules may be seen breaking through the epithelial wall on their way to the surface, Plate XVI, Fig. 7. Patten, 1884, in his embryological investigation of the Trichoptera shows that these tubules are evaginations of the proctodeum before the wall of the forming mesenteron is joined with that of the proctodeum. Further evidence of this is seen in sections of the intestine further back where the tubules may be seen forming within the epithelial tissue of the intestinal walls. The cells are still columnar but the presence of intima and the toss of the striated border indicate that this is no longer mesenteron, Plate XVI, Fig. 6. The Malpighian tubules are composed of large cells glandular in appearance, with a large nucleus in the center of the cell. The pigment so noticeable in gross structure now becomes more evident and stains darker than the nucleus and is not confined to a given region of the cell. There are three 
distinct layers; upon the inside is the lining or the intima, then the large celled wall and the covering which is muscular, Plate XVIII, Figs. 7 and 8 . The dorso-lateral and lateral tubules reach the surface posterior to the ventral pair.

Intestine: The transition to intestine in $H$. analis is accomplished with a mere constriction and change in cellular structure, but in $L$. indivisus there is a valve formed as the œsophageal valve is formed, but reversed in its components, the upper part of the fold is slightly columnar in its cellular structure but covered with intima in a thin coat, the intima becomes thicker and the cells cubical as the folds turn toward the intestinal wall, Plate XV, Fig. 10. At the posterior edge of segment seven the cubical wall changes and becomes large celled with large nuclei, Plate XVI, Fig. 2. In $H$. analis this continues to the anterior margin of the ninth segment, Plate XVI, Fig. A at 2. At the beginning of the ninth segment the epithelial wall changes to a cubical condition which changes only as the wall becomes differentiated into the blood gills and returns to the cubical condition when this function ceases. The whole length of the intestine is thrown into six longitudinal folds which begin in the sixth segment, Plate XVI, Fig. 6, and is traceable through all the sections to the rectum where the semi-valve occurs and the four blood gills arise. The folds do not continue into the rectum. In $L$. indivisus transition in the eighth segment from the cubical celled condition to the large celled, which marks the end of the intestine in this form, is a distinct rectal valve not different in character or formation from the one into the intestine from the mesenteron; the cells of the wall of the rectum are large with large nuclei and this condition continues to within $.5 \mathrm{~mm}$. of the anus. It is possible to consider the rectum of $H$. analis as beginning at this level and the semi-valve as only the transition into the blood gills, but the gross anatomical structure seems to bear the former interpretation.

Musculature: The osophagus is surrounded with bundles of longitudinal muscles, outside of which is a layer of banded circular muscles and outside of these six pairs of longitudinal muscles so noticeable in gross structure. At the anterior end of the proventriculus the inside layer of longitudinal muscles cease and the proventriculus is immediately surrounded by circular muscles, (see Noyes 1915), which continue as a sheath of varying thickness for the full length of the alimentary canal as far as the rectum.

Mesenteron: The six pairs of longitudinal muscles break up into a layer of longitudinal muscles, this layer is composed of large bundles upon the outside and small ones upon the inside next to the thin circular muscles. See Plate XVI, Fig. 7.

Intestine: At the anterior end of this division where the cells of the epithelium are columnar but covered with intima, a heavy circular muscle arises pushing some of the longitudinal muscles outside and enclosing the smaller ones, Plate XVI, Fig. 6 . In a very few sections of $.008 \mathrm{~mm}$. in thickness this muscular wall is complete, Plate XVI, Fig. 5. The inner layer of circular muscles becomes thicker as we advance toward the posterior end of the canal and the inner longitudinal 
muscles have formed themselves into the characteristic six pairs and those pushed to the outside of the outer circular muscles have ceased, Plate XVI, Fig. 4. This heavy outer circular muscle comes to an end in the seventh segment, leaving the six longitudinal pairs as the exterior layer, Plate XVI, Fig. 3 . This condition prevails throughout segment eight, Plate XVI, Fig. 2, and past the semi-valve into the gill chamber of the rectum, Plate XVI, Fig. 1. For a diagram of this musculature, see Plate XVI, Fig. A, the levels drawn are numbered as the figures which are taken in cross section at these same levels. The musculature of $L$. indivisus does not vary from this description based upon $H$. analis, with the exception that in the mesenteron the longitudinal muscles are of a single layer, Plate XVI, Fig. S. The blood gills of $H$. analis rightfully belong to the discussion of the histology of the alimentary canal, but their structure is sufficient to claim for them a separate division of this paper.

\section{Blood Gills of Hydropsychodes analis Banks.}

Protruding from the T-shaped anus, Plate XV, Figs. 8 and 9 , Plate XVII, Fig. 1, are often seen four transparent, greenish, finger-like appendages, Plate XIV, Fig. 3. These are protruded beyond the limits of the anus when the larva is out of the water crawling upon the rocks, or may be artificially protruded by pressure upon the abdomen in the caudal region. Pictet, 1834, states that these appendages contain tracheæ. There are muscles leading into the gills which might be mistaken for tracheæ if the microscope were not of high magnification. Dufour, 1847, figures these gills as appendages from the rectum into the body cavity, but without tracheæ. This error of Dufour is easily understood when the larva is dissected, for it is almost, if not quite, impossible to open a larva from the dorsal side and not cut into the rectum so that these gills float out as though appendages from it. It is only when a lateral opening is made that the true internal position is observed. Fritz. Muller, 1888, does not show any tracheæ in the gills and Thienman, 1903, and Lubben, 1907, represent these as non-tracheæ bearing structures. In the glycerine mounts of the caudal end of the abdomen with the gills protruding from the anus, the tracheal tubes are seen to pass down the sides of the body sending branches to the alimentary canal and surrounding tissues. Long branches or continuations of the main tracheal trunks extend into the anal pro-legs or drag hooks, but in no instance does a single tracheole extend to a gill. In neither the transverse sections or the longitudinal ones does tracheal structure appear. Muscles and blood make up the content of the gill. These gills are in direct communication with the body cavity and it is possible that, when occasion renders the supply of oxygen insufficient, the blood rushes from the blood sinuses into these "pockets" and comes with sufficient force and quantity to extend the gill and push it to the exterior and an exchange of gases takes place through the wall of the gill. This action, combined with the lack of tracheæ, seems sufficient evidence upon which to claim the term of true blood gills for these structures. 
When retracted these gills lie within the rectum, which serves a double function, with their distal ends or tips close to the anus and just barely within the aperture. They may function slightly at this time.

In surface view the gills present a cylindrical form which tapers as it extends distally. Upon the surface are transverse ridges which are bounded by thread-like depressions. These depressions are as deep as the ridges are wide, for these ridges are made up of rings of cells one cell deep and one cell wide. At rest these cells are cubical, being as deep as they are wide, and the depressions are the expansion spaces between the cells. In expansion this ring of cells becomes narrower in diameter and the cells themselves wider and more shallow. Compare Plate XVII, Fig. 6, where the gill is at rest, and Fig. 7, where it is in extended condition. The tips of the gills are more dense and of a darker color than the rest of the gill. This condition is due, no doubt, to their close proximity to the anal aperture and to the fact that they must at times push their way through waste material in their extension.

To get a clear conception of the formation of these gills, it is necessary to start with their origin in the wall of the intestine in the ninth segment. Here the glandular large celled condition of the intestinal wall ceases and becomes cubical. The wall is thin and the six longitudinal folds extend inward so as to form a semi-valve at the head of the rectum, Plate XVII, Fig. 4. Gradually these folds merge into four and form the four gills. Plate XVII, Fig. 5, shows these longitudinal folds merging into the gills and being continuous with them. After the formation of the gill the rectal wall does not again fold, but passes directly to the anus.

At rest the width of the gill is about one-third its length, which normally is slightly less than the width of the ninth segment. The gill is capable of extension to about three times its normal length, and at this time the wall becomes thin and the cells much longer than deep. Not all of this extension length is made by the gill itself, as the folds at the head of the rectum extend and the caudal wall of the rectum itself is carried down with the gills, Plate XVII, Fig. 7.

The deep cells of the walls of the gills are possessed of large nuclei and are glandular in appearance. These cells take up about fourfifths of the diameter of the gill when at rest, leaving the other fifth for the muscle which extends from the conjunctiva of the lateral and ventral walls between segments eight and nine. Each gill possesses a muscle which arises at a corresponding place upon the conjunctiva and extends to the tip of the gill. Each gill muscle is three branched, Plate XVII, Fig. 8, and when at rest lines the gill. The gills are covered with a very thin intima, which is continuous with that of the rectum and intestine.

\section{GLANDS.}

Not all the glands in the body of the trichopterous larvæ are con-sidered here. The writer has confined her attention to the silk glands, the thoracic glands and the glands in the head, in this last only those in $L$. indivisus have been studied. 
The Silk Glands: Of all the glands of the trichopterous larvæ these are the most prominent. They practically fill the part of the body cavity not occupied by the alimentary canal and extend from the labial spinneret into the seventh segment. They are opaquely white, having a pinkish cast in a fresh specimen. Their content is sticky and if the glands of a fresh specimen be broken in dissection the secretion will so glue the organs and tissues together as to make further dissection impossible. This difficulty is remedied by applying Gilson's preservative to the freshly opened specimen and allowing it to remain for fifteen or twenty minutes.

Upon the floor and in the center of the anterior edge of the labium is a spinneret, Plate XVIII, Fig. 3, at sp. This is connected to a single tube of $.2 \mathrm{~mm}$. in length. In this region is the silk press composed of muscles which control the flow of secretion. This structure does not differ from the structure of the forms studied by Gilson, 1894, and needs no further discussion in this paper. At the posterior margin of the labium this single, slender tube becomes divided into two and passes ventrad of the nerves extending from the sub-œsophageal ganglion to the mouth parts. On reaching the ganglion each member of the pair of tubes passes laterad of the ganglion, Plate XVIII, Fig. 4, and then approaches its mate and passes with it underneath the œsophagus. At the posterior margin of the sub-œsophageal ganglion the tubes change their character from that of a duct to a true gland. In the duct the cells are small with simple nuclei. Externally the change is marked with a depression as though a thread were fastened tightly around the tube. Back of this depression is the gland proper, composed of an outer wall with an irregularly shaped nucleus in a flattened cell. This outer wall is two cells in circumference, the cells are hexagonal with the lateral face in a triangle. The front face of the triangle meets the posterior face of the triangular side of the other cell, see Plate XVIII, Fig. 5. Inside of this wall, which is frequently very loosely applied, is the inner tube consisting of a firm cylindrical wall, where the secretion is formed and inside of this heavy wall is a narrow tube through which the secretion passes to the duct, Plate XVIII, Figs. 6 and 6 .

These silk glands lie ventrad of the alimentary canal throughout the thorax and frequently as far as the second abdominal segment. Finally they make their appearance at the sides of the alimentary canal and increase in size. They extend to the sixth segment where they turn forward again and extend to the second and third abdominal segment, turning backward they reach to the seventh segment where the distal ends are frequently folded under the intestine or float free among the various folds of the Malpighian tubules, Plate XV, Fig. 1. For a detailed description of these glands see Vorhies, 1908.

Thoracic glands: Gilson, 1896, shows Phryganea grandis as possessing three glands or pairs of glands in the thorax, one pair to each of the segments. These glands are formed of small tubes which come together to form a small reservoir from which a single tube extends. This tube meets its fellow and together as one tube they open to the exterior in a small pore. Henseval, $1895-6$, did not find the three pairs in all of the 
forms studied but found a compound gland in the prothorax. This is the condition of $L$. indivisus and $P$. interrupta, although the structure of the two glands is not the same. In $P$. interrupta it resembles the glands found by Gilson in $P$. grandis and is much branched, Plate XVIII, Fig. 9, and Plate XIV, Fig. 2, ggl. The gland in L. indivisus is single and lies above the prothoracic ganglion; its opening is between the connectives of this ganglion to the sub-œsophageal and connects with a spinneret which lies at the extreme anterior margin of the prothorax and extends forward under the head, Plate XV, Fig. 1, at ggl, Plate XVIII, Fig. 1, ggl, and Fig. 10 . In $H$, analis a gland, corresponding to this gland of Gilson, has not been found.

\section{Glands in the Head of Limnophilus indivisus Walker.}

In the head are six pairs of glands exclusive of the silk glands. Lucas, 1893, Henseval, 1895, and Russ, 1907, mention two pairs and term them mandibular and maxillary glands. L. indivisus possesses these two pairs and others. The mandibular gland is situated on the outer angle of the mandibular sclerite and is composed of a number of single celled glands or "pockets" which open into a common duct. This common duct leads to the base of the sclerite, the name of which it bears, Plate XVIII, Fig. 14. The maxillary gland, as Lucas so terms the second of the head glands, is similar to the mandibular but is composed of many more of the small single celled glands. The two glands lie underneath the œsophagus with their several small lobes folded upon each other and their ducts extending almost at right angles from each other. These ducts open into the buccal cavity at the inner margin of the mandibular sclerite, Plate XVIII, Fig. 13. Patten, 1884, states that they are an invagination of the inner margin of the mandibular sclerite in the embryo and Patten terms them salivary glands. Further ventrad in the lead lies a multicellular gland in the maxillary sclerite with an opening into the distal end of this sclerite, Plate XVII, Fig. 12. In the labium we find a pair of similar glands, Plate XVIII, Fig. 11. With these glands hitherto undescribed, and which we must, from their position at least, term maxillary and labial glands, the so-called maxillary glands of Lucas present a problem for nomenclature. Lucas ventures the theory that the glands of the head are coxal glands and the homologs of the parapodal glands of the annelid. If this theory be accepted then the maxillary sclerites may not be possessed of two pairs of glands nor may the mandibular sclerites. The writer prefers to use Patten's name of salivary gland, for the maxillary gland of Lucas.

Glands also exist at the base of the antennæ and below the visual area, but these are not figured.

Circulatory system of $L$. indivisus: This is simple as in all insects and consists of the dorsal vessel which extends from the ninth segment of the abdomen to the head, where it spreads out upon the supraœsophageal ganglia. There are nine pairs of alary muscles beginning between the metathoracic and first abdominal segments and continuing to lie between the segments as far back as between the eighth and ninth. The first four are slender but the remaining five are heavy and connect with the one in front and behind it. In front of each pair of muscles, a valve exists in the dorsal vessel, Plate XIV, Fig. 8. 


\section{BIBLIOGRAPHY.}

Betten, Cornelius. 1901. Aquatic Insects in the Adirondacks, N. Y. State Museum Bull. No. 47.

The Larva of the Caddis-fly, Molanna cinerea Hagen Jr. N. Y. Ento. Soc., Vol. X, pp. 147.

Binet, Alfred. 1894. Contribution a l'étude du system nerveux sous-intestinal des insectes. Journ. 1'Anat. et Physiol., XXX, 449-580.

Blanchard E. De la circulation dans les insectes. 1848. Ann. Sc. Nat. Zool. 3 ser. T. IX.

Du system nerveux des insects. Ann. Sc. Nat. Zool. 3 ser. T. V., pp. 273-379.

Brauer, A. 1909. Die Süsswasserfauna Deutchlands Heft $5 \%$ Trichoptera beard. v. G. Ulmer.

Bruntz, L. 1904. Contribution a l'étude de l'excretion chez les Arthropodes Archive de Biologie, Vol. XX, pp. 335.

Chun, C. 1876. Uber den Bau die Entwickelung und physiologische Bedeutung der Rectaldrüsen bie den Insecten. Naturforschenden Gesellsschaft, Zehnte Band.

Clark, Cora H. 1891. Caddice Worms of Stony Brook. Pysche 1891, p. 153.

Comstock, J. H. 1919. Introduction to Entomology.

Cottie, J. Th. 1881. Beitrage zur Kenntnis des Chorda supra-spinal der Lepidoptera und des central, peripherischen und sympathischen nervensystems der Raupen. Zeitschr. fur wissensch. Zool., 1881, Bd. 35, pp. 304-320.

Cummings, Bruce F. 1914. Scent Organs in Trichoptera. Proc. Zool. Soc. London, 1914, p. 459.

Dufour, M. Leon. 1847. Description et Anatomie d'une larve á branchies externes d'Hydropsyche. Ann. Sc. Nat. Zool., ser 3, Vol. VIII, p. 341.

Dujardin, Felix. 1850. Memorie sur le systeme nerveux des insectes. Ann. Sc. Nat. Zool., ser 3, Vol. XIV, pp. 195-206.

Faivre, E. 1857. Du cerveau des Dytisques considéré dans ses rapports avec la locomotion. Ann. Sc. Nat. Zool. ser 4, T 8.

Fernald, C. H. 1890. Rectal glands in Coleoptera. Am. Nat., Vol. 24, 1890, p. 100.

Gee, Wilson P. 1911. The Oenocytes of Platyphylax designatus Walker, Biol. Bul., Vol. 21, 1911, pp. 222-234.

Gilson, Gustave. Recherches sur les cellules secretant. LaSoie et les appareil Sericigens. (1) Lepidoptera La Cellule VI, 1890. (2) Trichoptera La Cellule $\mathrm{X}, 1894$.

On the segmentally disposed Thoracic Glands in the !arva of Trichoptera. Jr. Linn. Soc. London. Zool., Vol. 25, No. 164, pp. 407, 1896.

Hammar, A. G. 1908. On the Nervous System of the Larva of Corydalis cornutus. Ann. Ento. Soc. Amer., Vol. 1, No. 2.

Headlee, Thos. J. 1906. Blood Gills of Simulium pictipes. Am. Nat., Vol. 40, pp. 875.

Henneguy, L. 1904. Les Insectes, p. 463.

Henseval, Maurice. Etude compareé des Glands de Gilson, La Cellule XI, 1895-6. Les glands buccales des larva de Trichoptera. La Cellule XII, 1897.

Janet, Charles. 1898. Etudes sur les Fourmis, les Guepes et les Abeilles, Note 17.

Kellogg, Vernon, 1905. American Insects.

Kenyon, F. C. 1896. The Meaning and Structure of the socalled "Mushroom Bodies" of the Hexapod Brain. Am. Nat. Vol. 30, p. 643.

Klapalek, Fr. 1888. Metamorphoses der Trichoptera, Serie I. Arch. Landesdf. Bohmen. Bd. VI, No. 5.

Kolbe, H. J. 1893. Einführung in die Kenntnis der Insekten.

Krauss, W. C. 1884. Nervous System in the Head of Corydalis cornutus Linn. Psyche Vol. 4, p. 179. 
Lucas, R. 1893. Beitrage zur Kenntnis der Mundwerkzeuge der Trichopteren. Arch. f. Naturg. LIX, p. 285.

Lubben, Heinrich. 1907. Uber die innere Metamorphose der Trichopteren Zool. Jahrb. Abt. Anat. Bd. 24, pp. 71-128.

Marchal, Paul. 1892. Sur la motilite des tubes de Malpighi. Ann. Soc. Ento. Fr. T 61 Bulletin, p. CCLVI.

Marshall, Wm. S. The Early History of the cellular Elements of the Ovary of a Phryganid, Platyphylax designatus Walker. Zeitschr-wiss. Zool. Bd. 86, pp. 217, 1907.

On the Anatomy of the Dragon fly. Wisconsin Academy, Transactions 17, 1914.

Martynow, Von Andreas, 1901. Uber einige eigenthumliche Drüsen bei den Trichopteren larven. Zool. Anz. XXIV, No. 649, pp. 449.

Miall and Hammond. 1900. The Structure and Life History of the Harlequin fly. pp. 83.

Miall, L. C. 1905. Natural History of Aquatic Insects, Trichoptera, pp. 236.

Mlttler, Fritz. 1888. Larvae von Mücken und Haarflüglern mit zweierlei abwechselnd thatigen Athemwerkzeugen. Entomologische Nachrichten, Vol. 14, No. $18 ;$ p. 273.

Needham, MacGillivray, Johannsen, Davis. 1903. Aquatic Insects in New York State Mus. Bull. 68, Ento. 18.

Needham, J. G. 1897. Digestive Epithelium of Dragon fly Nymphs. Zool. Bull., Vol. 1, No. 2.

- Noyes, Alice. The Proventriculus of an Hydropsyche Larva. Jr. Ento. \& Zool., Vol. 7, 1915.

Netspinning Insects of Cascadilla Creek. Ann. Ento. Soc. Amer., Vol. VII, No. 4, 1914.

The Ecology of the Hydropschidae and Philopotamidae of Rapid Streams (unpublished paper).

Packard, Alpheus S. 1898. A Text-book of Entomology.

Palmen, J. A. 1877. Zur Morphologie des Tracheensystems.

Patten, Wm. 1884. Development of Phryganids. Quat. Jr. of Micro. Soc., XXIV.

Pictet, Francois Jules. 1834. Recherches pour servir a 1'historie et l'anatomie des Phryganides.

Rambur, M. P. 1842. Histoire Naturelle des Insectes, Neuropteres.

Russ, E. L. Postembryonale Entwicklung des Darmkanals bei den Trichopteren. Zool. Jahrb. Abt. Anat. Bd. 25, pp. 675, 1907.

Beitrage zur Kenntnis der Köpfdrüsen der Trichopteren larven. Arch. Zool. Exp. 5 ser. T 5, 1910, N. R. LXI.

Schroder, C. 1912-13. Handbuch der Entomologie, Vol. I.

Siltala, A. J. 1907. Uber die Nahrung der Trichoptera Acta. Soc. Fauna Flora fennica Bd. 29, No.5.

Thienman, von A. 1903. Analkiemen bei den Larven von Glossosoma bolteni Curt. und einigen Hydropsychen. Zool. Anz. Bd. XXVII, Nr. 4.

Tutt, J. W. 1896. The Relationship of the lower Lepidoptera with Trichoptera. Entom. Rec. Journ. Var., Vol. 8, pp. 25-29.

Van Gehuchten, A. 1890. Recherches histologiques sur 1'appareil digestif de la larva de la Ptychoptera contaminata. La Cellule T VI, p. 185.

Vorhies C. T. The Development of the Nuclei of the Spinning Gland cells of Platyphylax designatus Walker. Biol. Bull., Vol. 15, pp. 54-61, 1908.

Habits and Anatomy of the Larva of the Caddis fly Platyphylax designatus Walker. Trans. Wis. Acad. Sc., Vol. XV, 1905.

Zander Enoch. 1901. Beiträge Z:r Mciphologie des Mannlichen Gescrilechtsanhange der Trichopteren. Zeitschr-wiss Zool., Bd. 70, p. 192. 


\section{EXPLANATION OF PLATES.}

\section{Plate XIV.}

Fig. 1. Central nervous system of Limnophilus indivisus and larval reproductive organs.

Fig. 2. Central nervous system of Phryganea interrupta and larval reproductive organs $\mathrm{gd} 1=$ gonad from the ental lateral aspect. $\mathrm{gd} 2=$ gonad frequently found and assumed to be the ovarian gonad.

Fig. 3. Central nervous system of Hydropsychodes analis and anal region with blood gills protruding from anus.

Fig. 4. Dorsal aspect of the supraœsophageal ganglia of Limnophilus indivisus.

Fig. 5. Lateral aspect of the supraœsophageal and subœsophageal ganglia of Limnophilus indivisus.

Fig. 6. Ventral aspect of subœsophageal ganglion of Limnophilus indivisus.

Fig. 7. Transverse section through the ovary of $H$. analis.

Fig. 8. Ventral aspect of the circulatory system of $L$. indivisus.

\section{Plate XV.}

Fig. 1. Lateral aspect of the alimentary canal of Limnophilus indivisus.

Fig. 2. Oesophageal valve of Limnophilus indivisus. The portion of the canal containing the valve has been slit longitudinally and the valve laid open.

Fig. 3. A transverse cut back of the œsophageal valve.

Fig. 4. Diagram to show the relative position of the Malpighian tubules at the division between mesenteron and hind intestine.

Fig. 5. Transverse cut through the recta! valve at a level with 5 in Fig. 1.

Fig. 6. Lateral section through the œsophageal valve. The cephalic end of the valve is toward the bottom of the page.

Fig. 7. Lateral aspect of the alimentary canal of Hydropsychodes analis.

Fig. 8. Caudal aspect of anus of Hydropsychodes analis.

Fig. 9. Dorsal aspect of the anus of Hydropsychodes analis.

Fig. 10. Longitudinal section through the division point between mesenteron and hind intestine showing a valve, caudad of the Malpighian tubules; and the folded digestive epithelium of the mesenteron.

Fig. 11. Ventral aspect of the alimentary canal of Phryganea interrupta, only the ventral pair of tubules are figured.

\section{Plate XVI.}

Fig. A. Diagram of the hind intestine of Hydropsychodes analis, with the levels at which the figures 1-6 are taken, indicated.

Fig. 1. Cross-section through the hind intestine at a point where a semi-rectal valve is formed by the invaginated folds of the intestinal wall.

Fig. 2. Cross section taken at level No. 2, showing the glandular structure of the large intestine.

Fig. 3. Cross section at level No. 3 , showing the six folds of the small intestine with the cubical cell in the wall and the ental layer of circular muscles with the six pairs of longitudinal muscles.

Fig. 4. Cross section at level No. 4, showing the ectal row of circular muscles in addition to the condition in Fig. 3.

Fig. 5. Cross section at level No. 5, showing the beginning of the columnar epithelial cells and the breaking up of the six pairs of longitudinal muscles into a layer of smaller longitudinal muscles. 
Fig. 6. Cross section at level No. 6, showing the Malpighian tubules forming in the hind intestine; also the breaking up of the ectal circular muscles. Note the presence of intima which indicates the structure as being a part of the hind intestine.

Fig. 7. A cross section slightly cephalad of the level of Fig. 6, showing the digestive epithelium in diagram and the heavy layer of longitudinal muscles characteristic of the mesenteron. The ventral pair of Malpighian tubules are seen here just coming to the surface.

Fig. 8. A portion of a cross section of the mesenteron of Limnophilus indivisus, which shows the normal two rows of muscles.

\section{Plate XVII.}

Blood Gills of Hydropsychodes analis.

Fig. 1. Cross section of anal region to show the T-shaped anus. $\times 70$.

Fig. 2. Cross section through the anus with a gill lying in the aperture. $\times 70$.

Fig. 3. Cross section through the rectum showing all four gills. $\times 70$.

Fig. 4. Cross section through the "so-called rectal valve." $\times 140$.

Fig. 5. Sagittal section of the gill region showing the intestinal wall invaginations that make the valve as at Fig. 4, and later make the gill wall itself and are continuous with the rectal wall caudad of the gills.

Fig. 6. Sagittal section of the gill region to show the retractile muscle of the gill and the relation to the body wall.

Fig. 7. Sagittal section of the gill region with the blood gills extended in function. $\times 125$.

Fig. 8. Cross section of a functioning gill showing the three muscle branches.

Fig. 9. The blood which fills the gills when in function. $\times 320$.

\section{Plate XVIII.}

Fig. 1. Dorsal view of the silk glands and Gilson's gland of $L$. indivisus.

Fig. 2. Ventral view of the mouth parts of $L$. indivisus with the silk glands located.

Fig. 3. Lateral aspect of the mouth parts of $L$. indivisus.

Fig. 4. Dorsal aspect of the silk glands in relation to the subœsophageal ganglion.

Fig. 5. Lateral aspect of a portion of the silk gland.

Fig. 6. Cross section of the gland proper of the silk gland of $H$. analis.

Fig. 6a. Cross section of the gland proper of the silk gland of $L$. indivisus.

Fig. 7. Longitudinal section of a Malpighian tubule.

Fig. 8. Cross section of a Malpighian tubule.

Fig. 9. Dorsal aspect of the Gilson's gland of $P$. interrupta in relation to the prothoracic ganglion.

Fig. 10. Dorsal aspect of the Gilson's gland of $L$. indivisus in relation to the prothoracic ganglion.

Fig. 11. Ventral aspect of the glands in the labial sclerite of L. indivisus. X 120 .

Fig. 12. Ventral aspect of the gland in a maxillary sclerite of L. indivisus. X 120 .

Fig. 13. Ventral aspect of the maxillary gland of Henseval and Lucas. $\times 30$.

Fig. 14. Ventral aspect of the mandibular gland. $\times 30$.

Fig. 15. Cross section of several of the unicellular portions of the maxillary gland of Henseval and Lucas. $\times 30$. 


\section{INDEX TO FIGURES.}

$a=$ anus.

$\mathrm{abg}=$ abdominal ganglia 1 to 8 .

abs =abdominal segment 1 to 9 .

ant $=$ antennal nerve.

af =alary muscle 1 to 9 .

$b=$ nerve to front of head.

bc = buccal cavity.

$\mathrm{bg}=$ blood gills.

$\mathrm{bm}=$ basement membrane.

$\mathrm{c}=$ crura cerebri.

$\mathrm{cr}=$ crop.

$\mathrm{cm}=$ circular muscles.

$\mathrm{cp}=$ corpuscle.

$\mathrm{ct}=$ conducting tubule.

dep $=$ digestive epithelium.

dh=drag hooks.

$\mathrm{dv}=$ dorsal vessel.

ep=epithelium.

ex $=$ expansion area.

excm = exterior circular muscle.

$\mathrm{fa}=$ frontal arm.

$\mathrm{f} g=$ frontal ganglion.

gd=gonad.

gd1 = gonad in inner aspect.

gd2= probable ovary of $P$. interrupta.

ggl=Gilson's gland.

glep=glandular epithelium.

gsp = spinneret of Gilson's gland.

in = intima.

$1=$ Lumein.

$1 b 1=$ labral nerve.

$1 \mathrm{~b} 2=$ labral nerve.

lb-s=labral sclerite.

$1 \mathrm{il}=$ labial nerve.

1 i2 = labial nerve.

li-s= labial sclerite.

1 -int $=$ large intestine.

$1 \mathrm{~m}=$ longitudinal muscle.

$\mathrm{md} 2=$ mandibular nerve. md-s $=$ mandibular sclerite. $\mathrm{me}=$ mesenteron.

$\mathrm{mp}=$ Malpighian tubule.

$\mathrm{mp1}=$ dorso-lateral pair.

mp2=lateral pair.

mp3= ventral pair.

$\mathrm{ms}=$ mesothorax.

$\mathrm{mstg}=$ mesothoracic ganglion

$\mathrm{mt}=$ metathorax.

$\mathrm{mttg}=$ metathoracic ganglion .

$\mathrm{n}=$ nucleus.

oe $=$ œsophagus.

$\mathrm{og}=$ opening of gland.

opt $=$ optic nerve.

oev $=œ$ sophageal valve.

or $=$ œsophageal ring.

$\mathrm{p}=$ pigment.

$\mathrm{pm}=$ gills press muscles.

pr $=$ proventriculus.

pro $=$ prothorax.

protg = prothoracic ganglion.

ptm = perotrophic membrane.

$\mathrm{r}=$ rectum.

$\mathrm{rm}=$ retractile muscle.

$\mathrm{rn}=$ recurrent nerve.

$\mathrm{rv}=$ rectal valve.

$r w=$ rectal wall.

$\mathrm{s}=$ sympathetic ganglion.

sb-oeg = sub-oesophageal ganglion.

spr-oeg = supra-oesophageal ganglion.

skc $=$ silk gland duct.

skp $=$ silk gland proper.

$\mathrm{sb}=$ striated border.

sm-int $=$ small intestine.

$\mathrm{sp}=$ spinneret.

$t=$ tubule.

tr = trachea.

$\mathrm{y}=$ ventral end of ovary. 


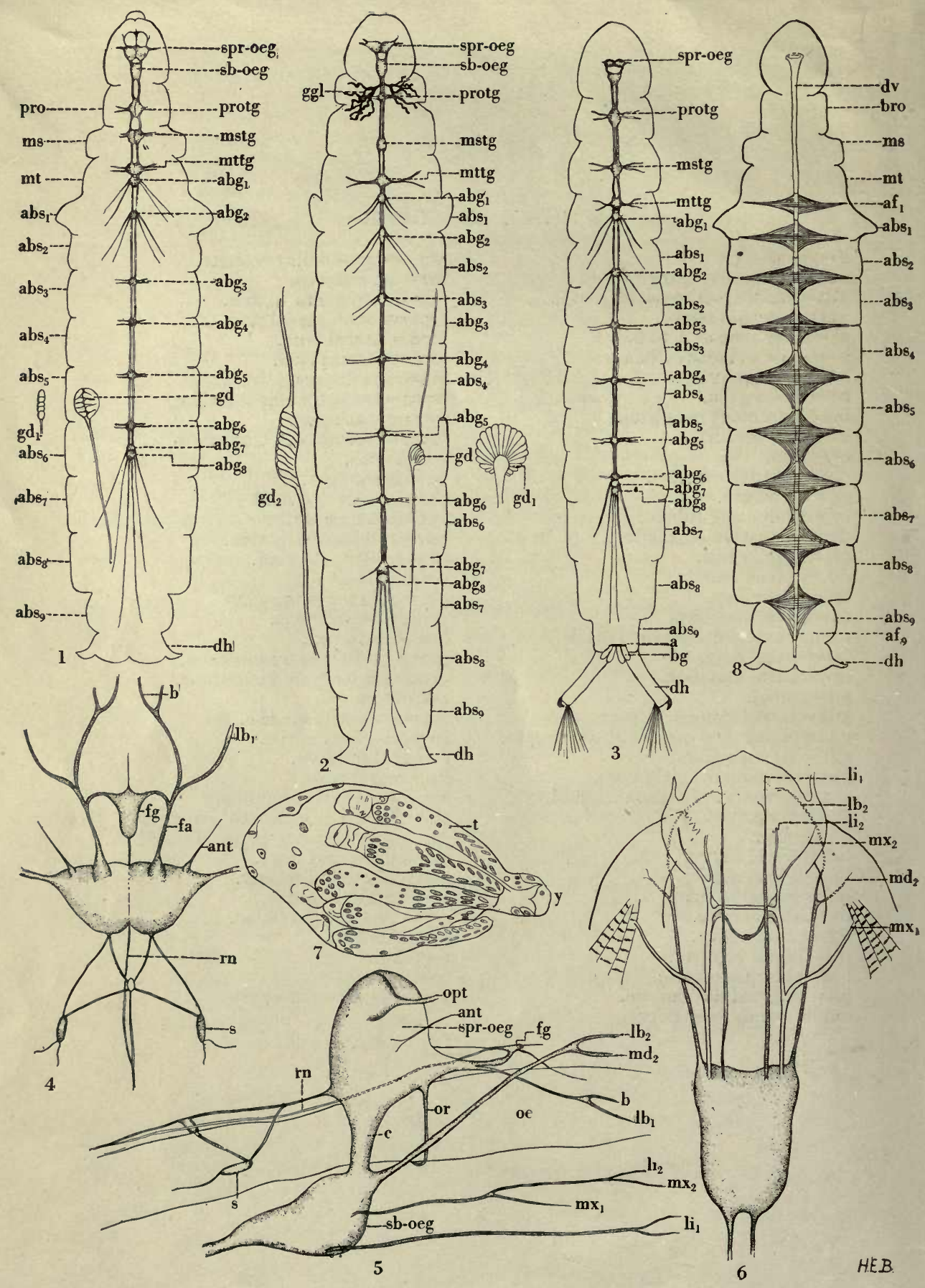

Hazel Elisabeth Branch. 


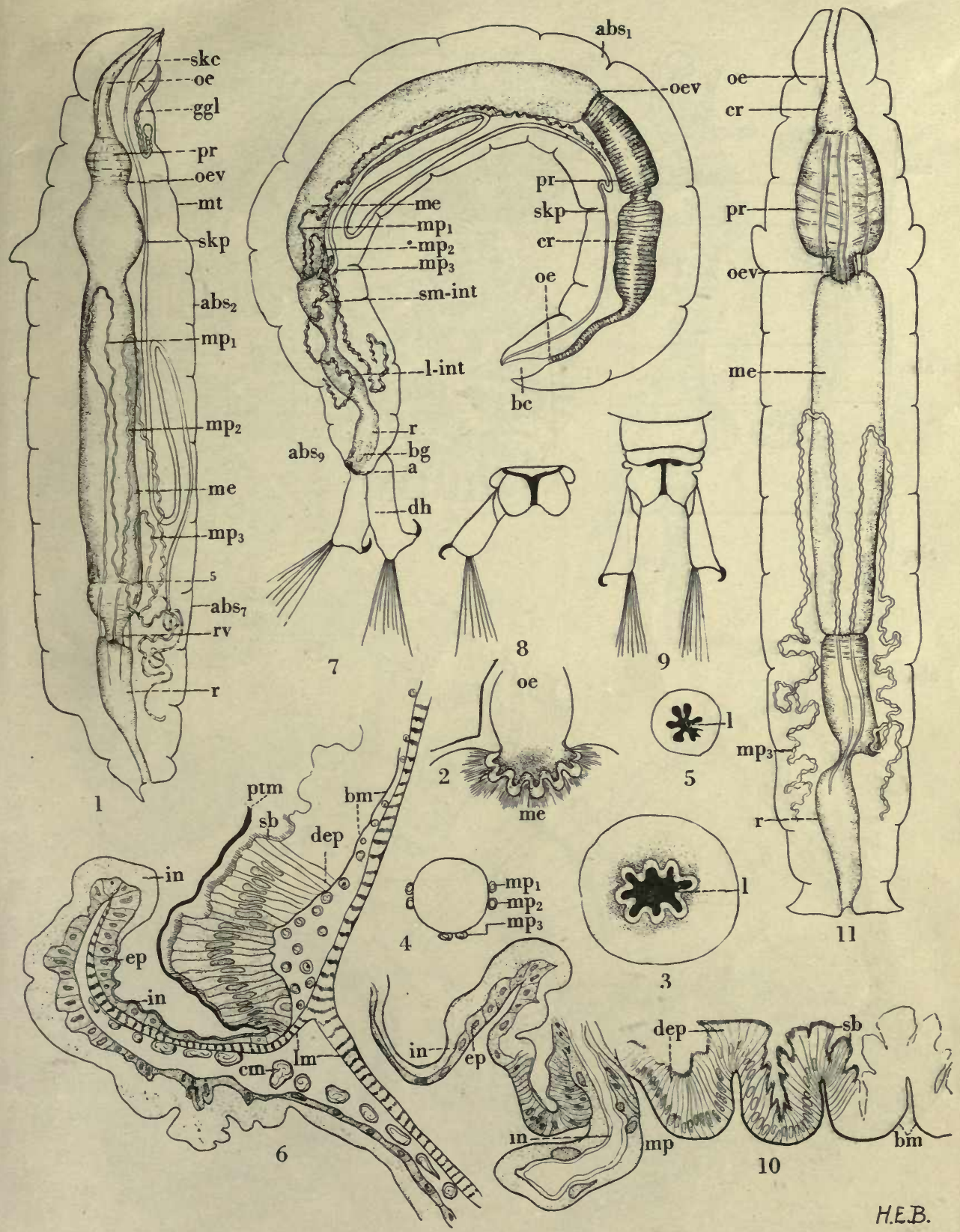

Hazel Elisabeth Branch. 


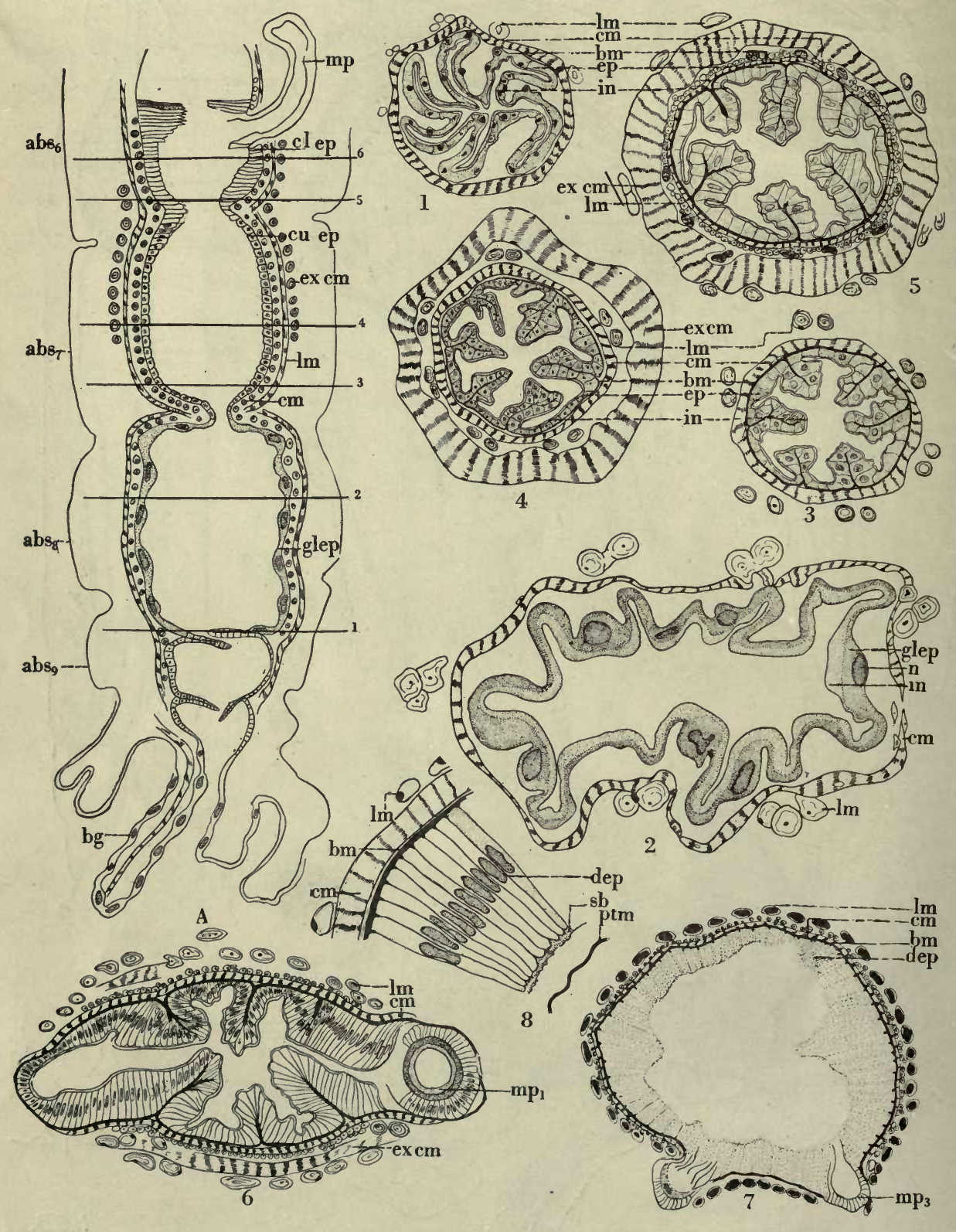

H. E. B.

Hazel Elisabeth Branch. 

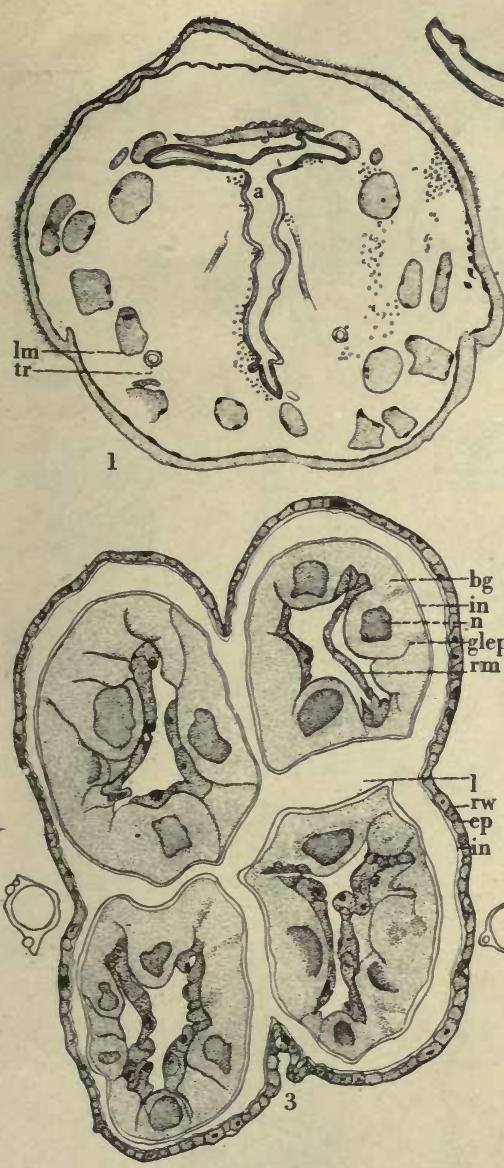

(2)

जियान ग

Q

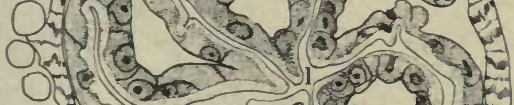

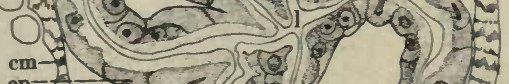

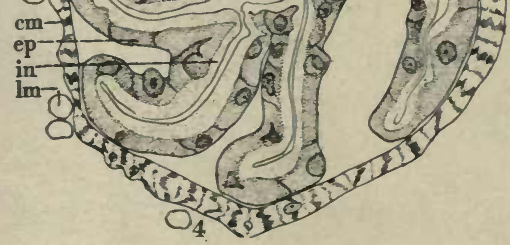

13
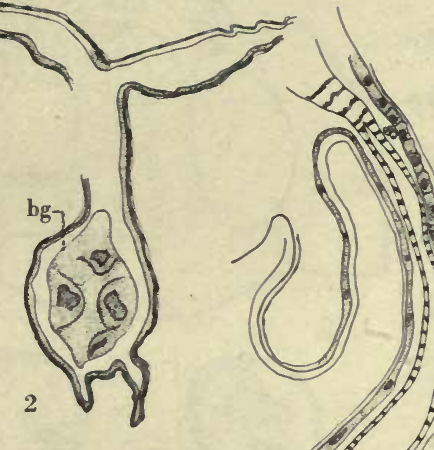

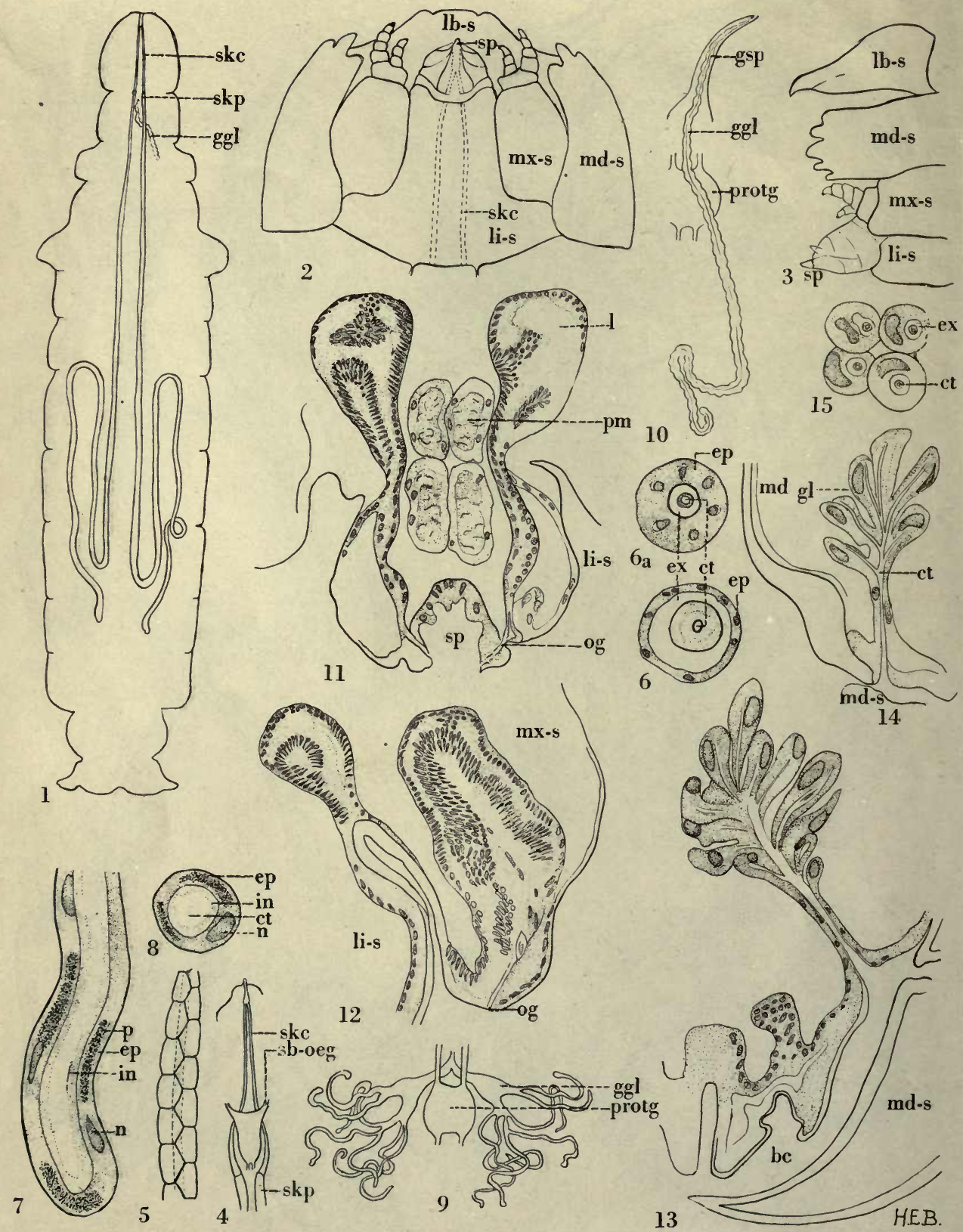

Hazel Elisabeth Branch. 
>

$+3$

.

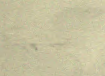




THIS BOOK IS DUE ON THE LAST DATE STAMPED BELOW

AN INITIAL FINE OF 25 CENTS WILL BE ASSESSED FOR FAILURE TO RETURN THIS BOOK ON THE DATE DUE. THE PENALTY WILL INCREASE TO 50 CENTS ON THE FOURTH DAY AND TO \$1.00 ON THE SEVENTH DAY OVERDUE.

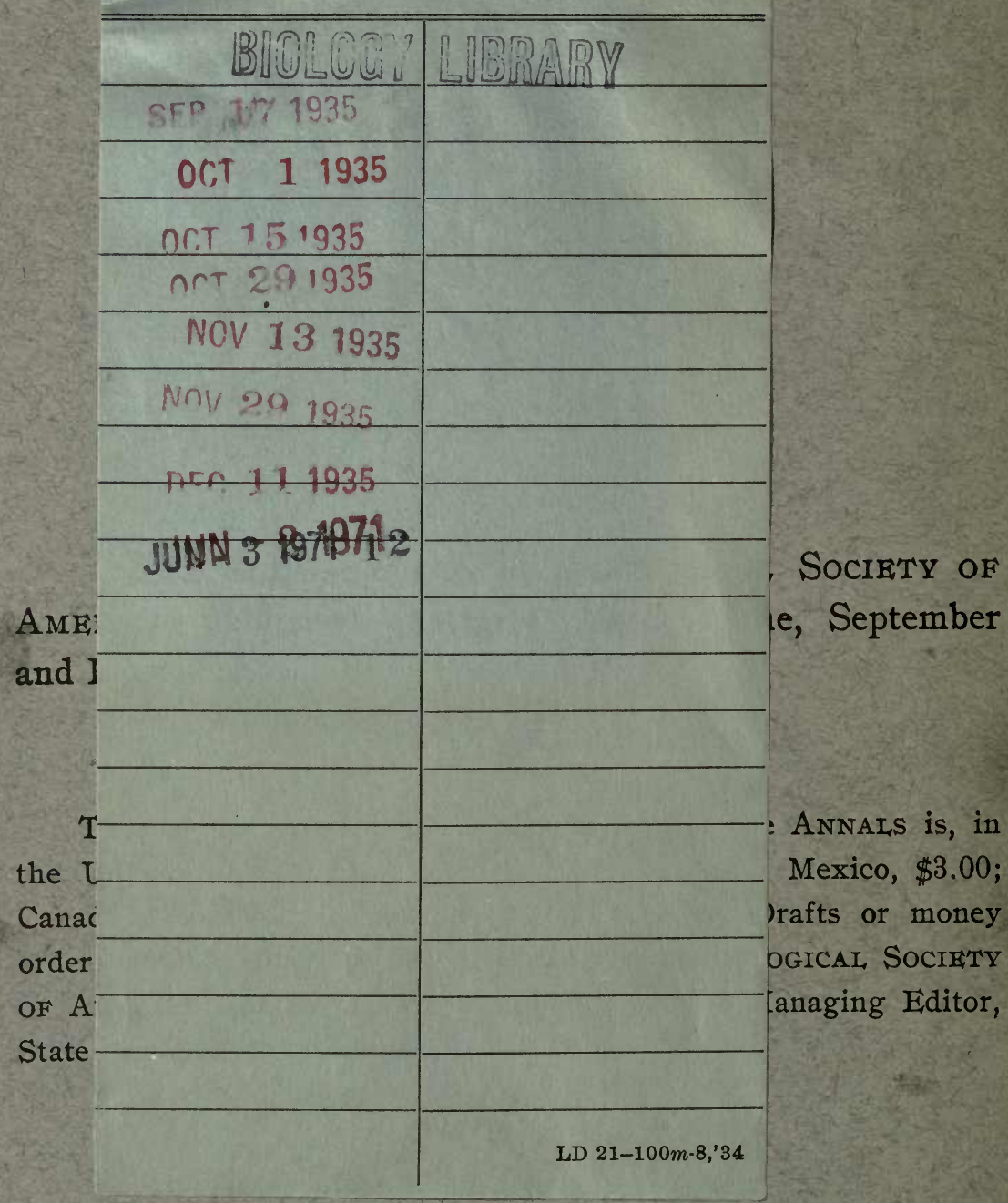




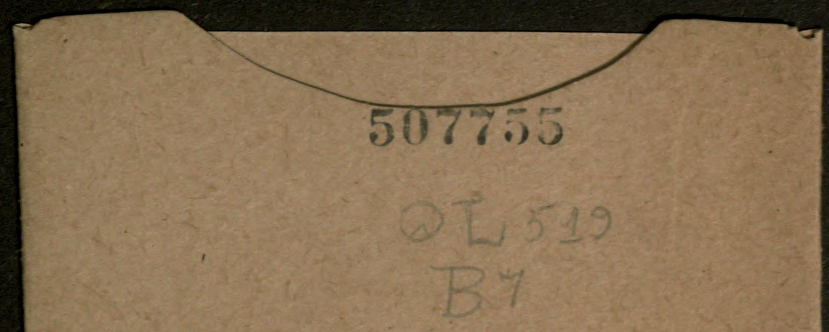

BIOLOGY
LIBRARY

G.

UNIVERSITY OF CALIFORNIA LIBRARY 
